\title{
Looking Back, Moving Forward: UN Peace Operations and Rule of Law Assistance in Africa, 1989-2010 - ERRATUM
}

\author{
Richard Zajac Sannerholm
}

doi:10.1017/S1876404512000206, published online by Cambridge University Press, September 2012

The note 'Looking Back, Moving Forward: UN Peace Operations and Rule of Law Assistance in Africa, 1989-2010,1 was not only written by Richard Zajac Sannerholm, but also by Frida Möller, Kristina Simion and Hanna Hallonsten. We apologise for this oversight and reproduce the entire corrected paper here.

\footnotetext{
${ }^{1}$ Richard Z. Sannerholm, 'Looking Back, Moving Forward: UN Peace Operations and Rule of Law Assistance in Africa, 1989-2010', in: 4 Hague Journal on the Rule of Law (2012), pp. 359373.
} 


\title{
Looking Back, Moving Forward: UN Peace Operations and Rule of Law Assistance in Africa, 1989-2010
}

\author{
Richard Zajac Sannerholm, Frida Möller, Kristina Simion \\ \& Hanna Hallonsten*
}

This article presents a bird's-eye view of two decades of UN rule of law assistance in Africa. The article is based on a dataset developed by the Folke Bernadotte Academy which covers a total of $36 \mathrm{UN}$ peace operations (peacekeeping, political missions and offices).

Implementing comprehensive rule of law strategies is challenging for the UN as a whole, not least where peace operations are deployed. Such operations are deployed in situations where the rule of law is severely tested and where in such environments UN staff perform a number of critical functions, ranging from developing national rule of law plans and strategies, coordinating national and international stakeholders, advising on justice matters and providing technical expertise on specific topics. For the two leading UN entities in relation to post-conflict societies, the Department of Peacekeeping Operations and the Department of Political Affairs, the translating of rule of law policy into practical programme activities is a daunting task, specifically in terms of providing assistance that is timely, situational and aligned with the national priorities of the host country.

While there have been many positive developments in the UN's rule of law system over the past decade in terms of policy, practical experience and competencies earned on the ground, observations made on the basis of empirical data raise a number of questions critical to the UN's future commitment to rule of law assistance in peacekeeping and peace-building.

\section{INTRODUCTION}

For the UN and the international community at large the rule of law has emerged as a central element in the maintenance of peace and security. ${ }^{1}$ Justice and the rule

* Richard Zajac Sannerholm, Jur Dr., Researcher and Project Leader at the Folke Bernadotte Academy. Frida Möller, MA Peace and Conflict Research, Research Assistant at the Folke Bernadotte Academy. Kristina Simion, LLM, Rule of Law Officer at the Folke Bernadotte Academy. Hanna Hallonsten, LLM, Project Assistant at the Folke Bernadotte Academy.

${ }^{1}$ The Security Council has included rule of law components in almost all thematic and countryspecific resolutions since 2003. See, Security Council Report, Cross-Cutting Report on the Rule of Law, no. 3, 2011, p. 15. 
of law are, together with security and democracy, seen to be mutually reinforcing imperatives in fragile post-conflict, peace, and state-building processes. While recent years have witnessed increased concentration by the UN on matters such as the rule of law and justice, the assistance accorded to states emerging from civil war has been fraught with difficulty - specifically on providing a comprehensive and integrated rule of law response, ensuring sustainable progress in the rule of law and the linking of rule of law assistance with peace-building and development.

This article provides a bird's-eye view of two decades of UN rule of law assistance in Africa between 1989 and 2010. This account draws on a dataset developed by the Folke Bernadotte Academy (FBA), covering a total of 36 UN peace operations (peacekeeping, political missions and offices). ${ }^{2}$

Between the increased demand for the rule of law in UN peace operations, and the attendant demands of putting the concept into practice, there is a scarcity of comprehensive empirical studies. Instead, there is a reliance on case studies, project or mission evaluations and lessons learned studies. Considering the efforts, time and resources invested in rule of law assistance, the absence of concerted efforts to describe empirically how the concept is realised is problematic. Without a systematic overview it is difficult to assess properly and appreciate past practices and to identify possible future trends, challenges and demands for rule of law assistance.

FBA's dataset on UN rule of law assistance covers seven broad reform areas: (1) judicial reform, (2) constitutional reform, (3) law reform, (4) the rule of law in public administration reform, (5) legal awareness and access to justice reform, (6) law enforcement reform, and (7) the reform of places of detention and prisons. The seven reform areas describe different aspects of rule of law assistance, but also instances where the rule of law forms part of parallel initiatives such as security sector reform. ${ }^{3}$ The dataset is composed of the Secretary-General's reports on UN peace operations. These reports provide regular updates on the situation in a peace operation and on the activities supported or implemented during a specific time period. $^{4}$

\footnotetext{
${ }^{2}$ Richard Zajac Sannerholm et al., UN Peace Operations and Rule of Law Assistance in Africa: Data, Patterns and Questions for the Future 2012.

${ }^{3}$ Transitional justice is not included in the dataset due to the fact that such initiatives are often pursued separately from general rule of law assistance. Reforms centred on human rights are included where they form part of broader justice reform efforts to realise and internalise international human rights in relation to one of the seven rule of law areas.

${ }^{4} \mathrm{~A}$ rule of law reform area is only included in the dataset when it is clearly mentioned in a report as an activity that is attributed directly to a specific peace operation (e.g., UNMIL's support for the training of magistrates or assistance in drafting a new law on criminal procedure). Work undertaken by other UN agencies - for example, UNDP or UNODC - is included if it is undertaken as part of joint programmes and activities within a specific peace operation.
} 
Seen over two decades, UN rule of law assistance has moved from being on the margins of peace operations to become a standard component in almost all new peace operations established by the Security Council. UN rule of law assistance is in the process of being professionalised. There is now a growing policy and doctrine, a support structure at headquarters, and training manuals and courses as well as 'how-to guides' on a number of topics of relevance for the police, or justice and correction officers in the field.

At the same time, this professionalization is confined to issues of law and order and justice chain institutions, while other reform areas such as constitutional reform, legislative support or access and awareness are given much less attention. The data analysed for this article suggests a path dependency in UN rule of law assistance in Africa in both peacekeeping and peace-building, but also in transitions between different missions.

This article argues that there is a need for the UN to strengthen its capacity to provide a broader rule of law assistance that is adaptable to different post-conflict environments. It is also important that the UN identifies ways in which cooperation between key entities such as DPKO, DPA and UNDP can be improved in the field and at the headquarters. Rule of law areas that today receive limited attention in peace operations are often cross-cutting issues without a clear 'entity home'. Properly addressing cross-cutting rule of law areas will be important for the UN to meet the present and future demand for rule of law assistance.

\section{UN Rule of Law Policy and Operational Guidance}

The rule of law has gradually emerged as a key objective in crisis management, with a more defined policy starting to form after 2000, influenced by practices developed and competencies earned in peace operations during the 1990s.

Following the UN's increased responsibility for rule of law assistance in peace operations, and particularly after the experience as an international administrator in Kosovo and East Timor, the need grew for a comprehensive and guiding definition. In 2004 the Secretary-General launched a common rule of law definition for the whole organisation in his report Rule of Law and Transitional Justice in Conflict and Post-conflict Societies, defining the concept as follows: 'a principle of governance in which all persons, institutions and entities, public and private, including the State itself, are accountable to laws'. The definition also lays down that laws should be publicly promulgated, equally enforced and independently adjudicated, and be consistent with international human rights standards. ${ }^{5}$

\footnotetext{
${ }^{5}$ UN Secretary-General, 'Rule of Law and Transitional Justice in Conflict and Post-Conflict Societies', S/2004/616, 23 August 2004, p. 4.
} 
The definition is ends-based and generally in accordance with how the rule of law is typically portrayed in legal doctrine and scholarly works. ${ }^{6}$ The institutional scope of the UN's definition is broad and sets out not only to encompass legal and judicial institutions, but also law enforcement, correction institutions and administrative agencies. The definition includes both substantive justice (i.e., the aims and outcomes of justice) and procedural justice (i.e., the process by which those aims and outcomes are achieved). In this sense the UN definition is 'thick' or 'material'. 'The emphasis is not only on having proper procedural guarantees, but also that the content and meaning of laws and regulations adhere to certain international standards.

Following the formulation of policy, several attempts have been made by the Secretary-General and different UN entities to provide concrete guidance by describing specific justice components, tasks and functions in rule of law assistance. One example:

Operational guidance is provided in the 2008 Guidance Note of the SecretaryGeneral: UN Approach to Rule of Law Assistance where, for the first time, a framework for strengthening the rule of law is introduced. The framework identifies a number of substantive and procedural elements in relation to constitutions, legal frameworks, and the implementation thereof. ${ }^{8}$

At the most practical level, and dealing directly with how to assess, programme, monitor and evaluate rule of law assistance, UN staff have at their disposal a number of guidelines and manuals on different rule of law areas. In 2006 and 2008 the Office of the High Commissioner for Human Rights (OHCHR) established a rule of law tool-kit consisting of five sets of instruments. ${ }^{9}$ The different tools are each considered to respond to some of the supreme tests and demands that UN entities typically face in crisis, conflict, and post-conflict societies, and are intended to be employed as practical guidelines in rule of law assistance. The DPKO has also developed a set of guidelines and manuals, chiefly covering law and order-related issues such as working with the police, justice and correction institutions. ${ }^{10}$ There are also a number of guidelines issued by other UN entities

\footnotetext{
${ }^{6}$ See, generally, the contributions in Gianluigi Palombella and Neil Walker (eds.), Relocating the Rule of Law 2009.

${ }^{7}$ For a discussion on thin or thick interpretations of the rule of law, see Brian Tamanaha, On the Rule of law: History, Politics, Theory 2004, pp. 91f.

${ }^{8}$ UN Secretary-General, Guidance Note of the Secretary-General: UN Approach to Rule of Law Assistance 2008, pp. 4-7.

${ }^{9}$ OHCHR, Truth Commissions 2006; Mapping the Justice Sector 2006; Prosecution Initiatives 2006; Monitoring Legal Systems 2006; Vetting 2006; Reparations 2008; and Hybrid Courts 2008.

${ }^{10}$ DPKO, Policy: Justice Components in United Nations Peace Operations 2009; Guidelines on the Methodology for Review of Justice and Corrections Components in United Nations Peace Operations 2009; DPKO Best Practice Guidelines: Executive Corrections Management in UN Peacekeeping 2003; and the United Nations Police Handbook 2005.
} 
such as UNODC, UNDP and UNICEF on matters of criminal law reform and access to justice. ${ }^{11}$

Thematically the guidelines and manuals chiefly cover law and order-related issues and leave other rule of law areas somewhat lacking in practical guidance, for instance constitutional reform and public administration. ${ }^{12}$ Moreover, there is no apparent hierarchy between the different guidelines and manuals, and it is difficult to assess to what extent they are actually used in peace operations. ${ }^{13}$ The fact that some of the guidelines and manuals are formulated for development cooperation, and others for post-conflict peace operations, might well impede ready access and use between the two fields.

Overall, the UN policy that has evolved - as stated in the reports of the Secretary-General - is comprehensive and positions the rule of law as a means for sustainable peace and security, as well as an end in (and of) itself. In this way the UN's commitment to the rule of law comprises many different elements, from law and order to economic development and democratic governance.

In the crystallization of $\mathrm{UN}$ rule of law policy, however, it is possible to observe a pattern of both 'sectorisation' and 'securitisation'. From the broader UN rule of law policy, where the concept is put forward as a 'principle of governance', the rule of law gradually assumes a specific institutional orientation and focus as it becomes linked with programmatic entry points for justice components in peace operations. This suggests that in the practical translation of the comprehensive rule of law policy provided by the Secretary-General, there is selectivity in terms of institutions and justice components. Most of the practical guidelines and manuals attend to problems and challenges that actors within the justice chain are confronted with, and only deal superficially with non-justice sector institutions and problems.

\section{Significant Increase in Rule of Law Assistance}

Considering that recent years have seen an increased focus by the UN on matters such as the rule of law and justice, and specifically considering the evolution of policy, practical guidelines and manuals, it is interesting to examine whether

${ }^{11}$ UNICEF, Handbook on Legislative Reform: Realising Children's Rights 2008; UNDP's Rule of Law and Access to Justice: Perspectives from UNDP Experience 2003; UNODC's Criminal Justice Assessment Toolkit: Legal Defence and Legal Aid 2006.

${ }^{12}$ The Secretary-General's Guidance Note on United Nations Assistance to Constitution-Making Processes, April 2009, covers the area only superficially while highlighting the pressing need to develop strategic guidance on methods to support national actors. On public administration, see, Per Bergling et al., Rule of Law in Public Administration: Problems and Ways Ahead in Peace-Building and Development 2008.

${ }^{13}$ Camino Kavanagh and Bruce Jones, Shaky Foundations: An Assessment of the UN's Rule of Law Support Agenda 2011, p. 61. 
there are correlations with a general increase in rule of law assistance in peace operations.

Since 1989 there has been a general increase in UN peace operations. Parallel with this growth has been the corresponding and significant expansion of rule of law assistance (Figure 1). During the first ten years covered by the FBA's dataset, more than half (12 out of 21 ) of the peace operations concerned were involved to a varying degree in rule of law assistance. From 2000 onwards, the proportion of peace operations providing rule of law assistance increased to a large majority (19 of 24). It is also possible to observe considerable peaks in rule of law assistance, and it is notable that in 2006 and 2008-2010, all peace operations in Africa were involved in one or several of the seven rule of law areas.

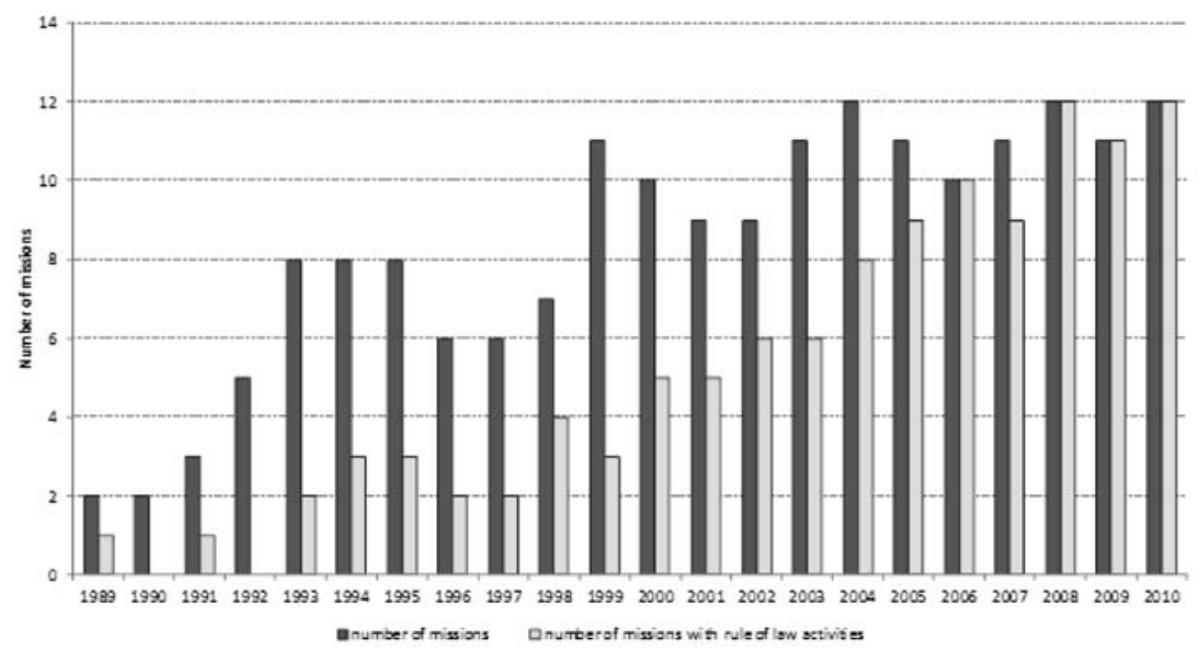

Figure 1. The total number of UN peace operations and the number of missions providing rule of law assistance, Africa 1989-2010

The high number of peace operations engaged in rule of law assistance demonstrates a comprehensive commitment on behalf of the $\mathrm{UN}$, and the prominent part that the rule of law has come to assume in conflict management.

The UN's commitment to rule of law assistance in Africa can also be examined in terms of the accumulated deployment of UN peace operations (e.g., combining all missions and their respective terms of deployment) and how much of the total deployment has been committed to rule of law assistance between 1989 and 2010. Of the accumulated deployment years of all peace operations in Africa, a majority $(57 \%)$ have engaged in rule of law assistance in one or several rule of law areas. 
The relatively large increase in volume over the past decade corresponds with organisational changes within the UN; for example, the establishment of OROLSI, the Rule of Law Coordination and Resource Group and the Standing Police Capacity and the Justice and Corrections Standing Capacity. The intensification of rule of law assistance also coincides with the evolution of policy and operational guidance at the UN Secretariat.

The steady and significant increase in volume after 2000 presents a challenge for UN rule of law assistance. If the past five years offer any projection for the future, there are no indications that calls for rule of law assistance will decrease. This raises fundamental questions for the UN - for example, is there sufficient capacity to handle simultaneously the high volume of rule of law assistance in many different conflict and post-conflict environments? However, the question is not only about handling an increased demand, but doing so with a high degree of quality, ensuring that rule of law assistance is timely, aligned with national priorities, and flexible to changes in a specific post-conflict transition. As the inventory on UN capacity in peace-building observed in 2006, there is generally limited capacity with regard to human resources with rule of law expertise within the UN and that in some areas, such as constitutional reform, the scarcity of capacity is striking. ${ }^{14}$ According to the report on $\mathrm{UN}$ civilian capacity in the aftermath of conflict, this situation in many ways appears to prevail today. ${ }^{15}$

The fact that more peace operations are engaged in rule of law assistance than ever before in Africa engenders a fundamental question as to what the intensification of rule of law assistance means for the organisation and its capacity to take on new responsibilities in rule of law assistance.

\section{Rule of Law Assistance Focuses on Law and Order Issues}

Considering the general increase in the rule of law in peace operations it is important to identify those areas where assistance is provided. The data shows that while the type of rule of law assistance has varied over time, the overall trend is one where justice chain institutions (e.g., the judiciary, law enforcement and detention and correction institution) stand for a significant portion of rule of law assistance in peacekeeping and peace-building (Figure 2).

The justice chain pattern is possible to identify over time and between different missions, starting with the early peace operations in Namibia, Angola and Mozambique and reinforced by more recent peace operations in countries such as Liberia, Sierra Leone and Sudan.

\footnotetext{
${ }^{14}$ UN Executive Office of the Secretary-General', 'Inventory', p. 46.

15 'Civilian Capacity in the Aftermath of Conflict: Independent Report of the Senior Advisory Group’, A/65/747-S/2011/85, 22 February 2011, p. 7.
} 


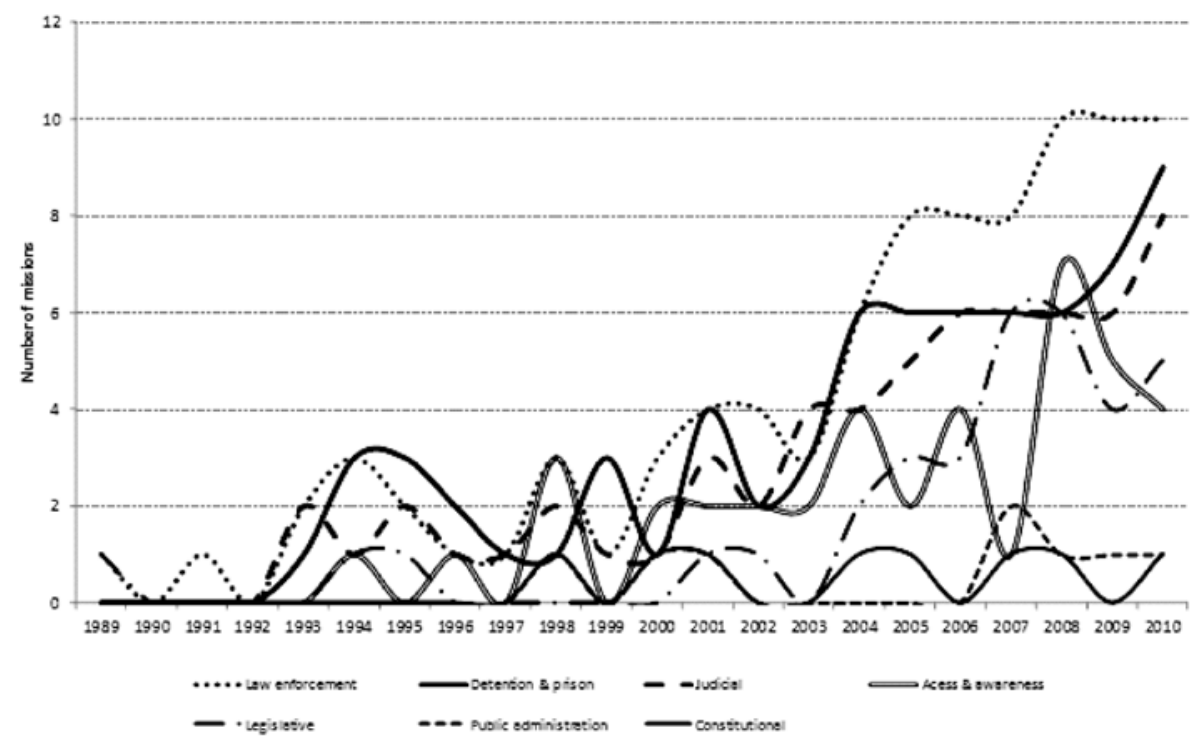

Figure 2. UN Peace operations involved in rule of law reform areas, Africa 1989-2010

From the mid-2000s, rule of law assistance increased dramatically in terms of the number of peace operations with reported rule of law assistance. This also coincides with an expansion of rule of law areas, thus increasing the prevalence primarily of access and awareness and legislative reforms. The rule of law in relation to public administration is only reported in isolated instances, thus lacking in levels of consistency, detail and prevalence compared with rule of law assistance found in other areas. In Sudan, for instance, UNMIS supported training initiatives organised by the Ombudsman office and provided logistical support to harmonise administrative divisions, while the UN in Sierra Leone assisted the Anti-Corruption Commission. Besides these, and a few other reported instances, the reform of public administration receives limited attention in UN rule of law assistance.

Overall, and among all peace operations taking part in rule of law assistance, there are notable differences in terms of the scope of involvement. At one end of the spectrum operations such as BONUCA in the Central African Republic, and UNIOSIL in Sierra Leone, engaged in all seven rule of law areas during one deployment year. At the other end, operations such as UNOMIL in Liberia embarked on only one reform area (places of detention and prisons) during a single deployment year.

The scope of rule of law assistance can be viewed in different ways. One of them is to count the number of missions that have been engaged in a specific activity. This demonstrates that law enforcement is the single reform area that most peace 
Table 1. Number and percentage of peace operations in relation to rule of law reform areas

\begin{tabular}{|l|c|c|c|}
\hline $\begin{array}{l}\text { Rule of law reform } \\
\text { area }\end{array}$ & $\begin{array}{c}\text { All UN operations } \\
\text { (36 missions) }\end{array}$ & $\begin{array}{c}\text { PKO operations } \\
\text { (22 missions) }\end{array}$ & $\begin{array}{c}\text { Political missions } \\
\text { G offices } \\
(14 \text { missions) }\end{array}$ \\
\hline $\begin{array}{l}\text { Police \& law } \\
\text { enforcement }\end{array}$ & 28 & 17 & 11 \\
$(78 \%)$ & $(77 \%)$ & $8 \%)$ \\
\hline $\begin{array}{l}\text { Prison \& } \\
\text { detention }\end{array}$ & 22 & 14 & $(57 \%)$ \\
\hline Legal access \& & $(61 \%)$ & 11 & 10 \\
awareness & 21 & $(48 \%)$ & $(77 \%)$ \\
\hline Judicial & $(58 \%)$ & 12 & 8 \\
& $(56 \%)$ & $(55 \%)$ & $87 \%)$ \\
\hline Law/legal & 15 & $(30 \%)$ & $(62 \%)$ \\
\hline Constitutional & $(42 \%)$ & 1 & 6 \\
& $(19 \%)$ & $(4 \%)$ & $(46 \%)$ \\
\hline Public & 5 & 1 & 4 \\
administration & $(14 \%)$ & $(4 \%)$ & $(31 \%)$ \\
\hline
\end{tabular}

operations have supported (Table 1). Viewing all UN operations, 28 out of 36 $(78 \%)$ were at some point during their deployment engaged in law enforcement reform. If the data is disaggregated further, variations between peacekeeping and peace-building emerge. For example, a number of political missions or offices have engaged in constitutional reform and public administration, while only one out of 22 peacekeeping missions focused on constitutional reform (MONUC in the Democratic Republic of Congo) and one on public administration (UNMIS in Sudan).

When examining UN rule of law assistance in Africa over time, what emerges is an orientation of a sectorised and securitised rule of law with specific 'core' rule of law areas - law enforcement, the judiciary and prisons. Here, the UN seems to have accumulated a considerable amount of practice and policy, and also to have made substantial commitments in terms of overall deployment. For instance, the Standing Police Capacity and the Justice and Corrections Standing Capacity testify to an increased preparedness in relation to these fields. The three major reform areas in the justice chain correspond to the burgeoning set of UN standards and practical guidelines and manuals now available for rule of law reformers. The fact that the justice chain was at the centre of the early peace operations in the 1990s, and has been so ever since, implies a form of path dependency. This path is reinforced by the practice of the Security Council when resolutions highlight or 
specifically identify institutions in the justice chain as priorities for rule of law assistance.

While the justice chain accounted for the majority of rule of law assistance initiatives during the first decade of peace operations included in FBA's dataset (1989-2000), it is possible to identify a pattern of broader rule of law assistance from 2000 onwards. Political missions and offices were not carried into effect until the late 1990s which may account for an increase in rule of law areas outside the justice sector.

The 2012 UN Secretary-General's report, Delivering Justice: Programme of Action to Strengthen the Rule of Law at the National and International Levels, raises the importance of also attending to rule of law challenges in relation to property and housing, civic records and combating corruption. ${ }^{16}$ Broadening the present rule of law focus to move beyond law and order, however, depends on the organisational capacity of UN entities involved in post-conflict rule of law assistance, primarily the DPKO and DPA. To that end the Secretary-General's proposed programme of action includes a call to member states to nominate civilian justice experts to support UN rule of law assistance.

In order to seize this opportunity, it should also be considered to what extent there is a need to develop a standing capacity in the UN on legislative, public administrative and constitutional reform areas similar to that of standing capacities for the police, justice and correction institutions. A broadening of present-day rule of law assistance to take in governance areas might also necessitate additional or specific guidance (manuals, tools etc.) on how to work on rule of law areas outside the justice chain in order to ensure the consistency of policy and practice.

The key focus on law and order and justice chain institutions leads to a situation of discrepancy between UN rule of law policy (the rule of law as a 'principle of governance') and UN rule of law in practice. While such accumulated practice indicates a positive resource mobilisation and a growing knowledge repository, the justice chain focus reflects only one part of the UN's rule of law policy. Looking at where most UN assistance ends up prompts a number of questions as to its flexibility and ability both to adapt and to contextually adjust rule of law assistance.

From the perspective of broadening the UN's rule of law assistance, the relationship between DPKO (and also to some extent DPA) and other UN entities working in post-conflict environments is of critical importance. The Security Council has stressed the importance of the clarity of roles and responsibilities

\footnotetext{
${ }^{16}$ Report of the Secretary-General, Delivering Justice: Programme of Action to Strengthen the Rule of Law at the National and International Levels, A/66/749, 16 March 2012, p. $8 f$.
} 
between peace operations and UN country teams 'for the delivery of prioritized support to a country consistent with its specific peace-building needs. ${ }^{17}$

In this regard the Peace-building Commission and the Peace-building Support Office have important parts to play in order to advise and propose strategies for better integrating peace-building tasks in peacekeeping missions, and generally on how peace operations can enhance cooperation with other entities on cross-cutting and interdependent matters such as constitutional reform and public administration. $^{18}$

Nevertheless, there are tensions between DPKO and 'development' entities within the UN system, particularly the UNDP. ${ }^{19}$ There also seems to be a deeper conceptual difference between UN entities on peacekeeping and development when it comes to framing, prioritising and the capacity to act upon long-term peace-building issues. ${ }^{20}$

In an attempt to introduce clear roles and responsibilities, and in order to enhance the coordination of UN rule of law assistance, the Secretary-General established a division of labour and a system of lead entities through Decision 2006/47. ${ }^{21}$ At country level, the lead includes coordinated planning and strategy development as well as the coordination of programme implementation with all the relevant partners.

The DPKO is the lead agency in conflict and post-conflict environments with a thematic mandate covering the strengthening of national justice systems and institutions, working with the police and law enforcement, prisons, interim law enforcement agencies, and security support to national law enforcement agencies. The UNDP is described as the lead agency in strengthening national justice systems and institutions where DPKO-led missions do not exist, with a thematic focus on court administration, civil and customary law, traditional and community-based justice, training, and land and property rights. ${ }^{22}$

The division of labour manifests a close link between the rule of law and security. The basket of long-term development is instructed to 'closely mirror those

${ }^{17}$ UN Security Council, 'Statement by the President of the Security Council', S/PRST/2011/4, 11 February 2011.

${ }^{18}$ The Peace-building Commission was established by Security Council resolution, S/RES/1645, 20 December 2005.

${ }^{19}$ Kavanagh and Jones, Shaky Foundations, at p. 61, though over the years the DPKO and UNDP have attempted to enhance their joint programming, see, UN Secretary-General, 'Strengthening and Coordinating United Nations Rule of Law Activities' A/66/133, 8 August 2011 p. 17.

${ }^{20}$ DPKO \& DFS, 'Peace. Keep It. Build It', November 2011, p. 15.

${ }^{21}$ UN Secretary-General, 'Uniting Our Strengths: Enhancing United Nations Support for the Rule of Law', S/2006/980, 14 December 2006, pp. 13-16. The decision is controversial and has been rather problematic to put into effect.

${ }^{22}$ UN Secretary-General, 'Uniting Our Strengths: Enhancing United Nations Support for the Rule of Law', S/2006/980, 14 December 2006, p. 13. 
activities being undertaken in the context of conflict and post-conflict societies. ${ }^{23}$ Thus, while seeking to maximise UN rule of law assistance by delineating thematic responsibilities and situational responses, the division embeds a securitisation of rule of law reform in peace operations, and for long-term development as well. Peace operations are often the most visible presences on the ground, but are illequipped to deal with long-term peace-building and development priorities. ${ }^{24}$

Sometimes Security Council mandates explicitly try to address and ensure that integrated missions and the UN's 'Delivering as One' agenda go some way towards enhanced cooperation in and the coherence of field activities. For post-conflict peace operations specifically, planning tools such as the Integrated Mission Planning Process and other similar mechanisms have also been developed to further integration, but their implementation seems to be inconsistent. ${ }^{25}$

Considering the dominant pattern of law and order and justice chain institutions in peace operations, specifically operations under the responsibility of the $\mathrm{DPKO}$, it is important that the structures and mechanisms for joint cooperation between different $\mathrm{UN}$ entities are further strengthened in order to better and more consistently address cross-cutting rule of law areas outside the law and order and justice chain focus.

\section{More of the Same: Transitions between Peacekeeping and Peace-building Missions}

Successful rule of law interventions depend on the flexibility of adjusting the response to evolving post-conflict challenges. Another conditional factor is the ability to address long-term issues early on and to lay the foundations for peace, security and development in the immediate period of post-conflict reconstruction. It is therefore important to examine what happens when there is a transition from a peacekeeping to a political mission.

Political missions are rarely deployed as the first peace operations on the ground but follow a peacekeeping mission in several cases. The transition from peacekeeping to peace-building is problematic for practical and financial reasons. As noted in the Secretary-General's 2011 report on funding for political missions, there is currently an inability to scale up back-stopping capacity for peacekeeping mission

${ }^{23}$ UN Secretary-General, 'Uniting Our Strengths', at p. 13.

${ }^{24}$ UN Department of Peacekeeping Operations, 'A New Partnership Agenda: Charting a New Horizon for UN Peacekeeping' (2004), pp. 22-23.

${ }^{25}$ Kavanagh and Jones, Shaky Foundations, at pp. 63-64. See also, UN, 'United Nations Integrated Mission Planning Process (IMPP)', Guidelines Endorsed by the Secretary-General, 13 June 2006. 


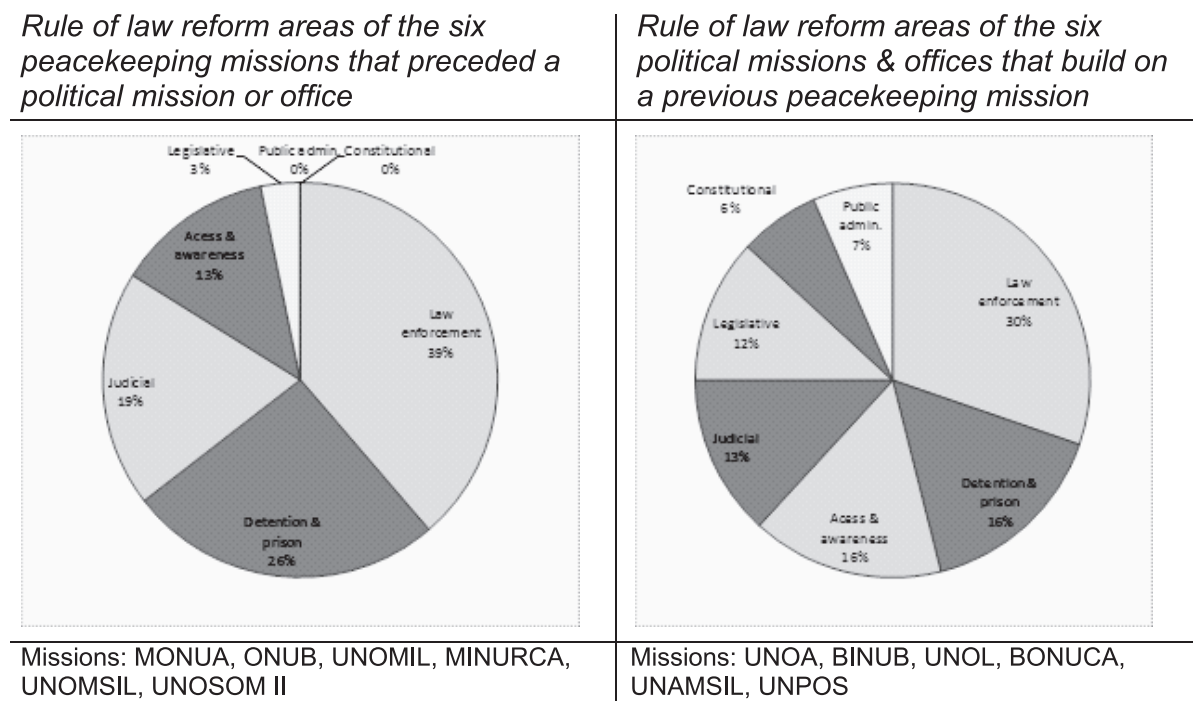

Figure 3. Sequencing of rule of law reform areas in Africa 1989-2010

transitions to political missions. ${ }^{26}$ This means that peace-building often lacks access to funds, staff and expertise in the area of the rule of law, and cannot easily draw on the resources of the DPKO.

In 1989-2010 six political missions and offices were deployed in Africa, building on previous peacekeeping operations. ${ }^{27}$ Of interest here is whether the DPAled operations provide a different type of rule of law assistance from those of the peacekeeping missions that they replaced.

There are notable variations in the transition from peacekeeping to peacebuilding. Reform areas of access and awareness, and law enforcement, detention and prison, and the judicial sector are pursued in both, with some variations. A major difference, however, is that peacekeeping operations provide very little or no attention to constitutional, legislative, or public administration reforms compared with political missions and offices. This indicates that political missions and offices continue in large part the rule of law assistance of peacekeeping missions, but also that there exists a broader scope of assistance in terms of the number of reform areas included.

${ }^{26}$ Report of the Secretary-General, 'Review of Arrangements for Funding and Back-stopping Special Political Missions', 12 October 2011, p. 10.

${ }^{27}$ UNOA after MONUA (Angola), BINUB after ONUB (Burundi), UNOL after UNOMIL (Liberia), BONUCA after MINURCA (Central African Republic), UNAMSIL after UNOMSIL (Sierra Leone), UNPOS after UNSOM II (Somalia). 
If the division of labour between the responsibilities for different rule of law areas is motivated by ideas that transitions from peacekeeping to peace-building will be progressive and adjusted to new context realities, then past practices provide limited guidance.

The data suggests that peace-building following directly on from peacekeeping provides more or less the same type of assistance. Six political missions have been deployed directly after a peacekeeping mission. Of these six, Liberia and Burundi started as peace-building, but were later replaced by peacekeeping as the situation deteriorated before political missions were once again established. Another instance, Côte d'Ivoire, started as a political mission but is now a peacekeeping mission. The differences that can be observed in transitions, paying greater attention to non-justice chain areas, might also be a reflection of peace operation realities. Political missions and offices lack the financial strength, the capacity to deploy personnel rapidly, and the logistics of peacekeeping missions. As a consequence, political missions and offices are more dependent on support from UN Country Teams and other UN entities present in the host country, which might explain the broader scope of rule of law assistance.

The practice of transferring responsibility for non-justice chain areas to peacebuilding means that many rule of law areas are not addressed immediately after a conflict settlement has been brokered and an international force is deployed, but rather depend upon a would-be future transition to a political mission or that structures and mechanisms to ensure support from the UN Country Team are in place while the peacekeeping mission attends to justice chain demands.

\section{Concluding Remarks}

This article presents an account of UN rule of law assistance in Africa between 1989 and 2010, drawing upon a comprehensive, empirical and systematic review of reports from the Secretary-General on UN peace operations and an inventory of UN policy and standard-setting documents, frameworks, practical guidelines and manuals on rule of law assistance.

In the past ten years covered by the FBA's dataset several changes have occurred within the UN rule of law system - for example, the establishment of a Rule of Law and Resource Coordination Group, supported by a Rule of Law Unit in the Executive Office of the Secretary-General, and the Office of Rule of Law and Security Institutions at DPKO. Moreover, a Police Standing Capacity and a Justice and Corrections Standing Capacity have been set up. There is also a continuing debate on capacity, roles and responsibilities in rule of law assistance. Several recent strategic reviews, for instance, the Senior Advisory Group's Independent Report on Civilian Capacity and DPKO's and DFS' Peace: Keep it. Build it, confirm the 
importance of the rule of law in peacekeeping and peace-building while highlighting the attendant difficulties of conducting successful programmes and reforms.

Though considerable effort has been made and progress achieved with regard to policy formulation, organisational restructuring and the development of tools, manuals and frameworks, past practices and what seems to be path dependency in UN rule of law assistance raise several critical questions relating to the organisation's flexibility with regard to post-conflict reality, the ability to provide a context-adjusted response, and the coherence and use of policy and practical guidance. The data presented in this article demonstrates that public administration, legislative reform, constitutional reform, and access and awareness play a small part in UN rule of law assistance in peace operations where the focus is chiefly on law and order and justice chain institutions. When these areas actually form a part of rule of law assistance they are addressed only to a relatively low extent in peacekeeping and peace-building. The UN, in particular the DPKO with the assistance of the UN rule of law support structure (e.g., the Rule of Law Unit, the Rule of Law and Resource Coordination Group) should assess past practices and bridge critical capacity gaps in areas outside the law and order focus. One way to achieve this is to enhance and extend good practices, innovations and accumulated experience in relation to police reform, judicial reform and prisons and places of correction to encompass a broader range of rule of law areas.

The UN's extensive and long-term support for post-conflict and crisis societies has established certain core capacities that should be reinforced, and this experience could be used to expand rule of law assistance to better reflect the organisation's commitment to the rule of law as a principle of governance. 